\title{
Mais evidências contra Terapia de Reposição Hormonal na menopausa
}

Em 2002, a Terapia de Reposição Hormonal (TRH) para mulheres na menopausa ganhou realce na mídia, face aos resultados do estudo Women's Health Iniciative (JAMA 2002; 288:321-33). As estimativas indicavam aumento do risco de doença cardiovascular e de câncer de mama entre as usuárias de estrógenos com progestágenos. Em 2004, a última parte do estudo foi encerrada: o uso de estrógenos associava-se a aumento do risco de derrame cerebral (BMJ News 2004; 328:540). Outros estudos trouxeram mais restrições: aumento de casos de demência, principalmente a doença de Alzheimer, e diagnóstico tardio de câncer coloretal entre as usuárias. Especialistas concluíram que os danos associados ao uso de TRH superavam os benefícios.

Mas, desde a década de 1990, já suspeitava-se que os alegados benefícios da TRH seriam decorrentes de distorções nos estudos observacionais. Neles, não se poderia controlar completamente a presença de outros fatores protetores. Assim, a proteção observada não seria relacionada à medicação, mas fruto de viés de seleção. Apesar das evidências, os órgãos governamentais e as instituições acadêmicas nacionais permanecem silentes sobre o assunto, tornando mais difícil a tarefa dos clínicos de tomar decisões terapêuticas. As dificuldades existem mesmo para aqueles com formação sólida em epidemiologia e em farmacologia; os demais ficam a mercê das informações enviesadas fornecidas pelos fabricantes de medicamentos.

Segundo Sackett (CMAJ 2002; 167:363-4), dada a freqüência com que o tratamento é prescrito, centenas de milhares de mulheres saudáveis têm sido prejudicadas. Ao se perguntar quem foram os vilões dessa história, ele responde: "eu culpo diretamente os especialistas médicos que, para auferir lucros privados (provenientes dos seus compromissos com a indústria), ou numa equivocada tentativa de fazer o bem, advogam medidas 'preventivas' que nunca foram validadas em ensaios randomizados rigorosos".

Entretanto, é preciso assinalar a imensa pressão dos fabricantes para preservar seus ganhos. Nos Estados Unidos, em 2000, a combinação estrógeno + progestágeno foi a segunda medicação mais receitada; em 2001, a venda de produtos rendeu US\$ 2 bilhões. Não é por acaso que a Wyeth Ayerst, diante da exigência de realização de ensaios randomizados para testar a alegada proteção cardiovascular, dizia serem eles inviáveis. A agressividade do comportamento dos fabricantes explica-se pelo contexto internacional. Há desregulamentação, há predomino da idéia de estado mínimo e de liberalismo nas relações econômicas. Como contrapartida, a sociedade precisa se organizar para substituir o estado omisso, multiplicando os agentes capazes de denunciar as irregularidades cometidas em nome de interesses econômicos.

Os aspectos mencionados acima transcendem o plano das idéias, pois estão ancorados em evidências científicas.

Mas há uma luta ideológica surda, que se trava toda vez que algum estudo aponta riscos, ou ausência de benefícios, relacionados aos medicamentos.

Nessa luta, é preciso nos posicionarmos. O Food and Drug Administration - agência norte-americana de regulamentação - já o fez. Lá, a terapia de reposição hormonal é recomendada apenas para alívio dos sintomas vasomotores, nas menores doses possíveis, e após pesar riscos e benefícios.

Suely Rozenfeld

Escola Nacional de Saúde Pública, Fundação Oswaldo Cruz, Rio de Janeiro, Brasil. 


\section{More evidence against Hormone Replacement Therapy in menopause}

In 2002, hormone replacement therapy (HRT) for menopausal women gained media visibility based on the results of the Women's Health Initiative study (JAMA 2002; 288:321-33). The estimates indicated an increase in the risk of cardiovascular disease and breast cancer among users of estrogens and progesterone. The final part of the study was concluded in 2004: estrogen use was associated with increased risk of stroke (BMJ News 2004; 328:540). Other studies identified further complications: an increase in cases of dementia, mainly Alzheimer disease, as well as late diagnosis of colorectal cancer among users. Specialists concluded that the harm associated with HRT outweighs the benefits.

However, since the 1990s it had already been suspected that even the purported benefits of HRT resulted from distortions in observational studies, in which it was impossible to completely control for the presence of other protective factors. The observed protection was not related to the medication, but resulted from a selection bias. Despite the evidence, Brazilian government agencies and academic institutions remained silent on the subject, thereby jeopardizing treatment decisions by clinicians. Difficulties exist even for those with a solid background in epidemiology and pharmacology; other health professionals remain at the mercy of biased information furnished by drug manufacturers.

According to Sackett (CMAJ 2002; 167:363-4), given the frequency with which HRT is prescribed, hundreds of thousands of healthy women have been harmed. When asked who the villains of this story are, he answers: "I place the blame directly on the medical 'experts' who, to gain private profit (from their industry affiliations), to satisfy a narcissistic need for public acclaim, or in a misguided attempt to do good, advocate 'preventive' maneuvers that have never been validated in rigorous randomized trials".

However, the huge pressure by manufacturers to protect their gains must be highlighted. In the United States in 2000, estrogen + progesterone combinations were the second most widely prescribed medication in the country; in 2001, revenue from HRT drugs totaled US\$ 2 billion. By no coincidence, when Wyeth Ayerst was faced with the requirement to perform randomized trials to test the alleged cardiovascular protection from HRT, the company claimed that such trials were unfeasible. Drug manufacturers' aggressive behavior is explained by the international context, predominated by deregulation, the notion of a minimum state, and liberalism in economic relations. On the other hand, civil society urgently needs to organize to replace the absent public sector, multiplying the number of actors capable of denouncing such irregularities committed in the name of economic interests.

The aspects discussed above transcend ideology, since they are anchored in scientific evidence.

Yet a muffled ideological struggle is waged whenever some study identifies either drug-related risks or absence of benefits.

We Brazilians must take a position in this struggle. The Food and Drug Administration (the U.S. regulatory agency) has already done so. In the United States, hormone replacement therapy is only recommended to relieve vasomotor symptoms, and even then at the lowest possible doses and after weighing the risks and benefits.

Suely Rozenfeld

Escola Nacional de Saúde Pública, Fundação Oswaldo Cruz, Rio de Janeiro, Brazil. 